\title{
Differential origin and control mechanisms in small and large bovine luteal cells
}

\author{
W. Hansel*§, H. W. Alila $\dagger$, J. P. Dowd* and R. A. Milvaeł \\ *Department of Physiology, Cornell University, Ithaca, NY 14853, USA; \\ †Animal Health Division, Smithkline Beecham, West Chester, PA I9380, USA; and \\ $\ddagger$ Department of Animal Science, University of Connecticut, Storrs, CT 06268, USA
}

Keywords: progesterone; protein kinase $\mathrm{C}$; intracellular calcium; prostaglandins arachidonic acid: luteal cells; cattle

\section{Introduction}

The ready accessibility of the bovine corpus luteum by enucleation through a slit in the anterior vagina (Casida, 1960) enabled researchers to conduct studies in vitro with accurately dated luteal tissue, without slaughtering the donor animals. These studies have led to the accumulation of a large part of the knowledge upon which our current concepts of control of the corpus luteum are based. In our own laboratory, an in-vitro technique, based on measurements of progesterone produced in a 2-h period by slices of bovine luteal tissue was developed in the early 1960 s to study the roles of the pituitary hormones on progesterone synthesis. Luteinizing hormone $(\mathrm{LH})$ proved to be the only significant pituitary luteotrophin (Hansel \& Seifart, 1967). Soon thereafter, it was established that LH exerts its luteotrophic effects through the cyclic AMP (cAMP) second messenger system (Savard, 1973). However, there were some reasons to doubt that all of the luteotrophic effects were mediated by cAMP. In bovine luteal slices, levels of LH too low to cause measurable increases in cAMP resulted in increased progesterone synthesis, and progesterone responses to increasing concentrations of LH continued to rise after cAMP production had plateaued. These same techniques also proved useful in early studies on the mechanism(s) of luteolysis in cattle. As early as 1966, Armstrong \& Black showed that the steroidogenic ability of LH in bovine luteal slices was lost between the 16th and 18th day of the cycle. Following the demonstrations of the luteolytic effects of prostaglandin (PG) F-2 $\alpha$ in sheep (McCracken et al., 1971) and cattle (Hansel et al., 1973), the effects of adding PGF-2 $\alpha$ to bovine (Hansel et al., 1973) and ovine (Fletcher \& Niswender, 1982) Juteal tissue were studied in vitro. Surprisingly, PGF-2 $\alpha$ stimulated rather than inhibited progesterone synthesis in vitro by bovine luteal tissues. However, synthesis was inhibited in ovine luteal tissues. This and other fundamental differences between ovine and bovine luteal tissues continue to be matters of considerable interest.

Over the years, this simple and useful technique has evolved into sophisticated techniques for cell dispersion and cell separation by fluorescence activated cell sorting. In addition, the development of the instrumentation for measurement of intracellular calcium by computer-driven spectrofluorometers has made it possible to study the role of calcium in the control of steroidogenesis in separated cells.

\section{Bovine luteal cell types and their separation}

Corner recognized that the corpora lutea of the sow (1919) and the rhesus monkey (1945) consisted of cells derived from both the granulosa and the theca interna in the follicle. McNutt (1924) concluded that bovine luteal cells were derived from both cell layers of the follicle, the granulosa producing the larger and the theca the smaller cells. Donaldson \& Hansel (1965) advanced the 
hypothesis that the granulosa-derived cells have a limited ability to divide, but that theca-derived small luteal cells retain the capacity to multiply and are capable of growing into large luteal cells under the influence of gonadotrophins during the oestrous cycle. Farin et al. (1989) have concluded that treatment of ewes with LH or human chorionic gonadotrophin induces transformation of small luteal cells into large cells.

Alila \& Hansel (1984) determined the origin of the large and small cell types in the bovine corpus luteum of the oestrous cycle and early pregnancy by the use of specific monoclonal antibodies to membrane preparations of theca interna and granulosa cells collected from bovine ovaries after the onset of oestrus and the LH surge and before ovulation. The large cells of the early cyclic corpus luteum were shown to be derived from granulosa cells. Very early in the cycle (Days 4-6) some small cells were also labelled by the granulosa antibody. However, the morphology of these cells resembled large cells and they were identified as granulosa cells that had not yet enlarged. All other small cells throughout the cycle and early pregnancy were derived from the theca interna. These results indicated that small cells can develop into large cells as the corpus luteum ages. At mid-cycle, it was estimated that less than half of the large cells present were bound by the specific granulosa cell antibody. In contrast, cells bound by the thecal antibody comprised the majority of luteal cells throughout the oestrous cycle and early pregnancy. The granulosa-derived antibody did not bind to any cells in the corpus luteum after the 100th day of gestation, while cells of thecal origin persisted throughout pregnancy.

The characteristics of the large and small bovine luteal cells have been described in detail by Hansel et al. (1987). The cells differ in a number of morphological features (Fig. 1). The small cells are distinguished by a peripherally located, deeply lobulated, cup-shaped nucleus with densely staining nucleoplasm and mitochondria arranged in an arc opposite the nucleus. The large cells tend to have central nuclei with distinct nucleoli and the mitochondria surround the nucleus. Some, but not all. large cells have numerous electron-dense, oxytocin-containing secretory granules in their cytoplasm.

The cell populations undergo dynamic changes in both the cow and the ewe during the reproductive cycle (Hansel et al, 1987; Farin et al., 1989). Although there is some disagreement as to the absolute numbers of large and small cells at various times during the bovine oestrous cycle, the large cells never account for more than $10 \%$ of the total luteal cell population (Hansel et al. 1987). O'Shea et al. (1989), using ultrastructural morphometry, estimated that large luteal cells make up $3.5 \%$ of the total cells at Day 12, and that the ratio of large to small cells is about $1: 8$. Unfortunately, these studies were carried out on corpora lutea from cows whose oestrous cycles had been synchronized by two injections of PGF-2 $\alpha$ adminstered 11 days apart, a treatment that results in reduced fertility (Smith et al., 1984) and alterations in luteal cell numbers and corpus luteum function (Hansen et al., 1987). Estimates of total cell numbers based on dispersion techniques are generally lower than those based on morphometric techniques, and losses during the dispersion and separation procedures probably occur as O'Shea et al. (1989) have indicated. In our own laboratory, the percentage of large cells currently recovered is about $9 \%$ of total luteal cells for Day-10-12 corpora lutea (M. Hinshelwood \& W. Hansel, unpublished observations).

Considerable effort has been devoted to developing efficient methods for quantitative separation of the large and small cells. Although highly purified preparations of small cells have been available for some time as a result of unit gravity sedimentation procedures (Koos \& Hansel, 1981), it was not until 1988 that Alila et al. developed procedures based on unit gravity sedimentation and fluorescence-activated cell sorting that resulted in large cell preparations of more than $90 \%$ purity. These methods were used in all of the experiments reported below and resulted in small cell fractions of $96 \pm 1 \%(n=30)$ purity and large cell fractions of $93 \pm 2 \%(n=6)$ purity.

\section{Control of steroidogenesis in large and small bovine luteal cells}

The control of progesterone production by the small and large luteal cells must be studied with highly purified cell preparations. A major reason for this requirement in that these cell types 


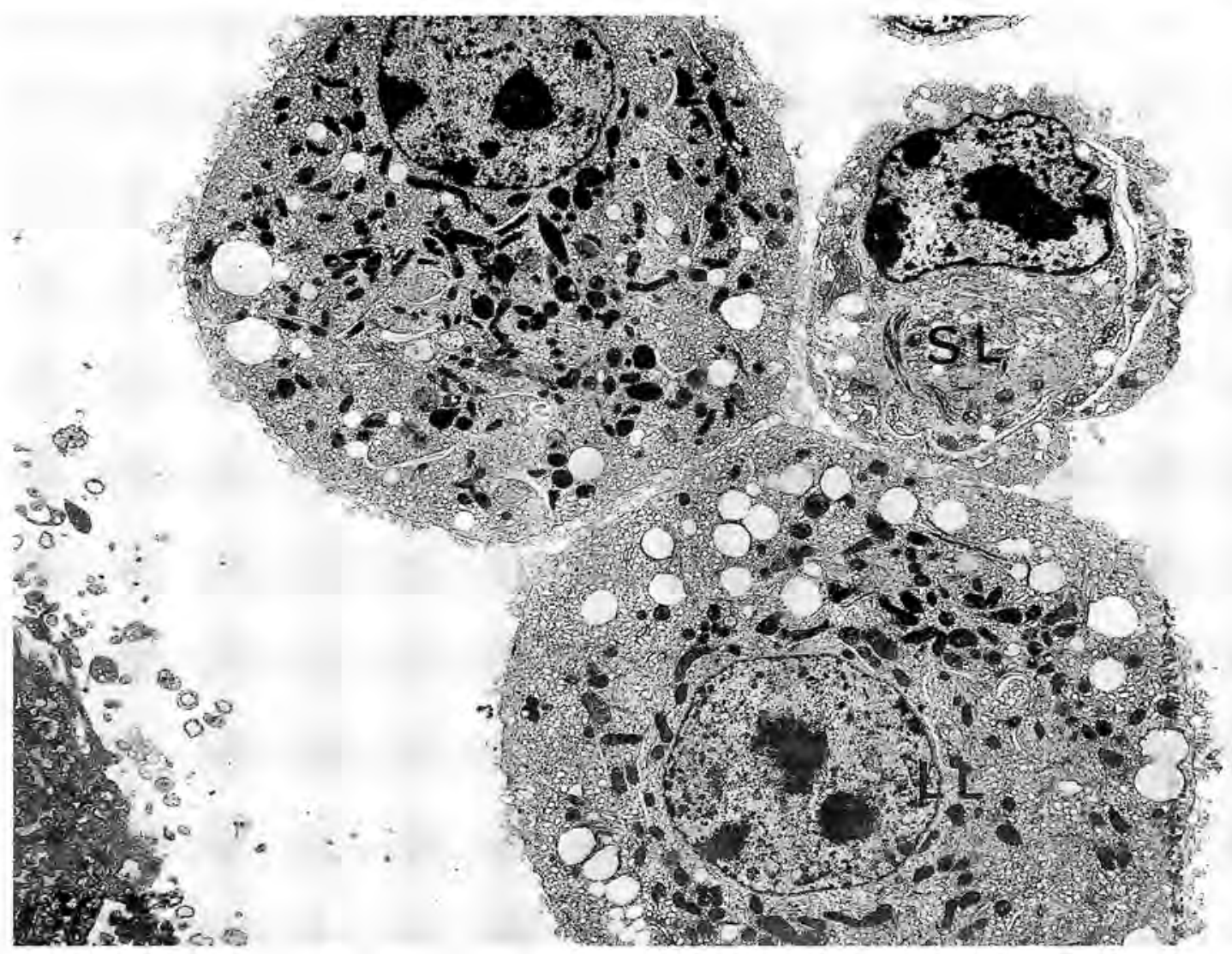

Fig. 1. Large (LL) and small (SL) cells from the corpus luteum of a cow, removed at Day 5 of the oestrous cycle. $\times 3610$.

interact in promoting progesterone production at mid-cycle, but may inhibit one another at luteal regression.

Preliminary data obtained in our laboratory with highly purified large and small bovine luteal cells support the hypotheses that: (a) during maintenance of the CL (Day 10-12), the large and small luteal cells synergize to promote the production of progesterone, and (b) during regression of the CL, this synergism is absent. Lemon \& Mauléon (1982) have obtained similar data for a synergism between the two cell types in the sow and Harrison et al. (1987) for the ewe.

Small luteal cells from bovine and ovine corpora lutea are extremely sensitive to added LH, while large cells from both species are relatively insensitive to LH (Alila et al., 1988a; Farin et al., 1989). However, large bovine luteal cells, in contrast to large ovine cells, do respond to high $(\geqslant 100 \mathrm{ng} / \mathrm{ml}$ ) concentrations of $\mathrm{LH}$ and to forskolin and 8-bromo-cAMP with an approximate doubling of progesterone synthesis. In contrast, addition of LH to small cells causes a 6-fold or more increase in progesterone production.

Dispersed sheep and cattle luteal cells also respond differently to added PGF- $2 \alpha$. In early studies, addition of PGF-2 $\alpha$ to total dispersed bovine luteal cells resulted in increased progesterone synthesis (Hixon \& Hansel, 1979) and in more recent studies (Alila et al., 1988a) this stimulation was shown to be limited to the small, theca-derived cells. PGF-2 $\alpha$ has no effect on basal production in large bovine luteal cells, but inhibits $\mathrm{LH}$, forskolin and 8-bromo-cAMP-stimulated progesterone, a result which suggests that these cells are the targets of the luteolytic action of PGF-2 $\alpha$ in vivo. The stimulatory effect of PGF-2 $\alpha$ on progesterone secretion is not found in ovine small luteal cells, 
but an inhibitory effect on $\mathrm{LH}$-stimulated progesterone production in large luteal cells, similar to that seen in bovine large cells, has been reported (Schwall et al., 1986).

With highly purified preparations of small and large luteal cells of cows (Alila et al., 1988b), basal progesterone secretion was increased in small cells by PGF-2 $\alpha$, PGE- 2 and PGI-2, but only PGF- $2 \alpha$ increased LH-stimulated production. In the large cells, PGF- $2 \alpha$ inhibited LH-stimulated production, as noted above, but PGE-2 and PGI-2 stimulated basal progesterone production.

\section{Role of protein kinase $\mathrm{C}$ in large and small bovine luteal cells}

Hansel \& Dowd (1986) reported that the $\mathrm{Ca}^{2+}$-polyphosphoinositol-protein kinase $\mathrm{C}$ second messenger system is involved in control of progesterone synthesis in the bovine corpus luteum and Brunswig et al. (1986) made similar observations. Both of these groups showed that phorbol esters capable of activating protein kinase $\mathrm{C}$ stimulated progesterone production in dispersed mid-cycle bovine corpora lutea. However, it was only after the development of efficient cell separation techniques that Alila et al. (1988a) were able to show that the stimulatory effect of phorbol esters is confined to the small cells. As in other cells, the effect of phorbol esters on progesterone production in bovine luteal cells is rapidly desensitized with chronic exposure. In contrast, the stimulatory effect of phorbol esters on prostacyclin production is not desensitized within a 24 -h period $(J$. P. Dowd \& W. Hansel, unpublished observations). To avoid problems associated with this differential desensitization of protein kinase $\mathrm{C}$ and prostanoid effects, we have continued to use short-term incubations of separated bovine luteal cells in our studies, rather than cultures of $24 \mathrm{~h}$ or longer.

Addition of active phorbol esters neither stimulated nor inhibited progesterone production by the large cells (Alila et al, 1988a). Attempts to inhibit progesterone synthesis in large cells by use of inhibitors of protein kinase $\mathrm{C}$ have given inconclusive results. Inhibition of progesterone synthesis has been observed after addition of staurosporine, but only at levels that are known to inhibit cAMP as well as protein kinase $C$.

Dowd et al. (1990) recently investigated the binding kinetics of the phorbol ester, $4 \beta$-phorbol 12,13-dibutyrate (PBt-2), to dispersed total bovine luteal cells, purified small cells and purified protein kinase $C$. Two distinct binding affinities were observed and characterized in the total cell preparations. However, only the high-affinity binding was observed in the intact small cells. The low-affinity, high-capacity binding found in total cell preparations must therefore exist in the large cells or in the accessory cells, which consist mainly of endothelial cells.

Cytosolic protein kinase $\mathrm{C}$ enzyme activity and the phorbol ester binding activity co-eluted during DEAE-Sephadex chromatography. Under conditions of saturating calcium and phosphatidylserine concentrations, binding of the protein kinase $\mathrm{C}$ preparations was found to be to a single receptor of high affinity, similar to that observed in intact small cells. It seems unlikely that the lowaffinity binding found in total cell preparations is due to one or more of the multiple isoforms of protein kinase $\mathrm{C}$, since binding affinities for each isotype in other tissues are reported to be quite similar. It seems more likely that the large cells contain protein kinase $\mathrm{C}$ but that it is sequestered in such a way that it is removed from phosphatidylserine and is thus unable to bind the phorbol ester with high affinity (Dowd et al., 1990).

The PGF- $2 \alpha$-induced increase in progesterone production by small bovine luteal cells therefore appears to be mediated by phospholipase C-induced phosphatidylinositol 4,5-bisphosphate hydrolysis, diacylglycerol generation and activation of protein kinase $\mathrm{C}$, rather than by increases in cAMP (Davis et al, 1988). LH, on the other hand, stimulates both the cAMP and the inositol 1,4,5trisphosphate $\left(\mathrm{IP}_{3}\right)$ diacylglycerol transmembrane signalling systems in bovine small luteal cells (Davis et al, 1989). Time-course studies have revealed that LH-induced increases in $\mathrm{IP}_{3}$ and cAMP occur simultaneously and precede the increases in progesterone secretion. A summary of the effects of LH, PGF-2 $\alpha, \mathrm{PBt}-2$ and phospholipase $\mathrm{C}$ on progesterone production in small and large bovine luteal cells is given in Table 1. 
Table 1. Summary of the effects* of $\mathrm{LH}_{\text {, }}$ PGF-2 $\alpha$, a phorbol ester (PBt-2) and phospholipase $\mathrm{C}$ in the control of progesterone synthesis in small and large bovine luteal cells (from Alila et al., 1988a)

\begin{tabular}{|c|c|c|}
\hline \multirow{2}{*}{$\begin{array}{l}\text { Compound(s) } \\
\text { added }\end{array}$} & \multicolumn{2}{|c|}{ Type of luteal cell } \\
\hline & Small & Large \\
\hline LH & $++t$ & + \\
\hline PGF-2 $\alpha$ & + & 0 \\
\hline $\mathrm{PBt}_{2}$ & + & 0 \\
\hline $\mathrm{PGF}-2 \alpha+\mathrm{LH}$ & $++t+$ & - \\
\hline $\mathrm{PBI}_{2}+\mathrm{LH}$ & +++ & 0 \\
\hline Phospholipase C & + & ND \\
\hline
\end{tabular}

The steroidogenic control mechanisms for small and large ovine luteal cells appear to be quite different from those in bovine luteal cells. Activation of protein kinase $\mathrm{C}$ inhibits progesterone production in small and large luteal cells incubated for $24 \mathrm{~h}$ before treatment (Wiltbank et al., 1989a) and in 2-h incubations of enriched small and large cells (Hoyer \& Marion, 1989). Other differences include the failure of small luteal cells of sheep to respond to PGF-2 $\alpha$ and the failure of large cells to respond to added $\mathrm{LH}$.

\section{Role of calcium in the control of steroidogenesis in bovine luteal cells}

The importance of mobilization of intracellular calcium $\left(\left[\mathrm{Ca}^{2+}\right]_{i}\right)$ as an integral part of the polyphosphoinositol-protein kinase $\mathrm{C}$ second messenger system necessitated further studies on the roles of calcium in progesterone production by the large and small bovine luteal cells. Initially, studies were carried out to determine the calcium requirements for both basal and stimulated progesterone synthesis by each cell type. Again, differential responses between the two cell types were seen and a remarkáble parallelism between progesterone production and intracellular calcium levels became evident.

Small cells, which contain relatively low resting $\left[\mathrm{Ca}^{2+}\right]_{i}$ levels, are extremely sensitive to $\mathrm{LH}$, and are able to produce basal levels of progesterone in the absence of calcium in the medium. However, progesterone synthesis stimulated by LH, PGE-2, 8-bromo-cAMP or PGF-2 $\alpha$ requires calcium ions (Fig. 2). cAMP production in the small cells was stimulated after addition of LH or PGE-2, but not PGF-2 $\alpha$, and cAMP production was not altered by low extracellular calcium ion concentrations. The effects of calcium ion removal appear to be exerted distal to cAMP generation in the small cells (Alila et al., 1988c).

In contrast, large cells, which contain high levels of resting $\left[\mathrm{Ca}^{2+}\right]_{i}$ and are relatively insensitive to $\mathrm{LH}$, require calcium ions for both basal and $\mathrm{LH}$ - and forskolin-stimulated progesterone production (Alila et al,, 1988a, 1989). Interestingly, 8-bromo-cAMP-stimulated progesterone production in large cells does not require calcium in the medium, suggesting that, unlike small cells, the inhibitory effect of calcium ion removal is exerted proximal to the generation of cAMP in these cells.

Experiments carried out with 8-N,N'-diethylaminocytyl-3,4,5-trimethoxybenzoate (TMB-8), an inhibitor of intracellular $\mathrm{Ca}^{2+}$ release and/or action in large and small cells, provided further evidence for these conclusions. TMB-8 suppressed both basal and LH-stimulated progesterone production in large cells, but only LH-stimulated production in the small cells. Addition of an 

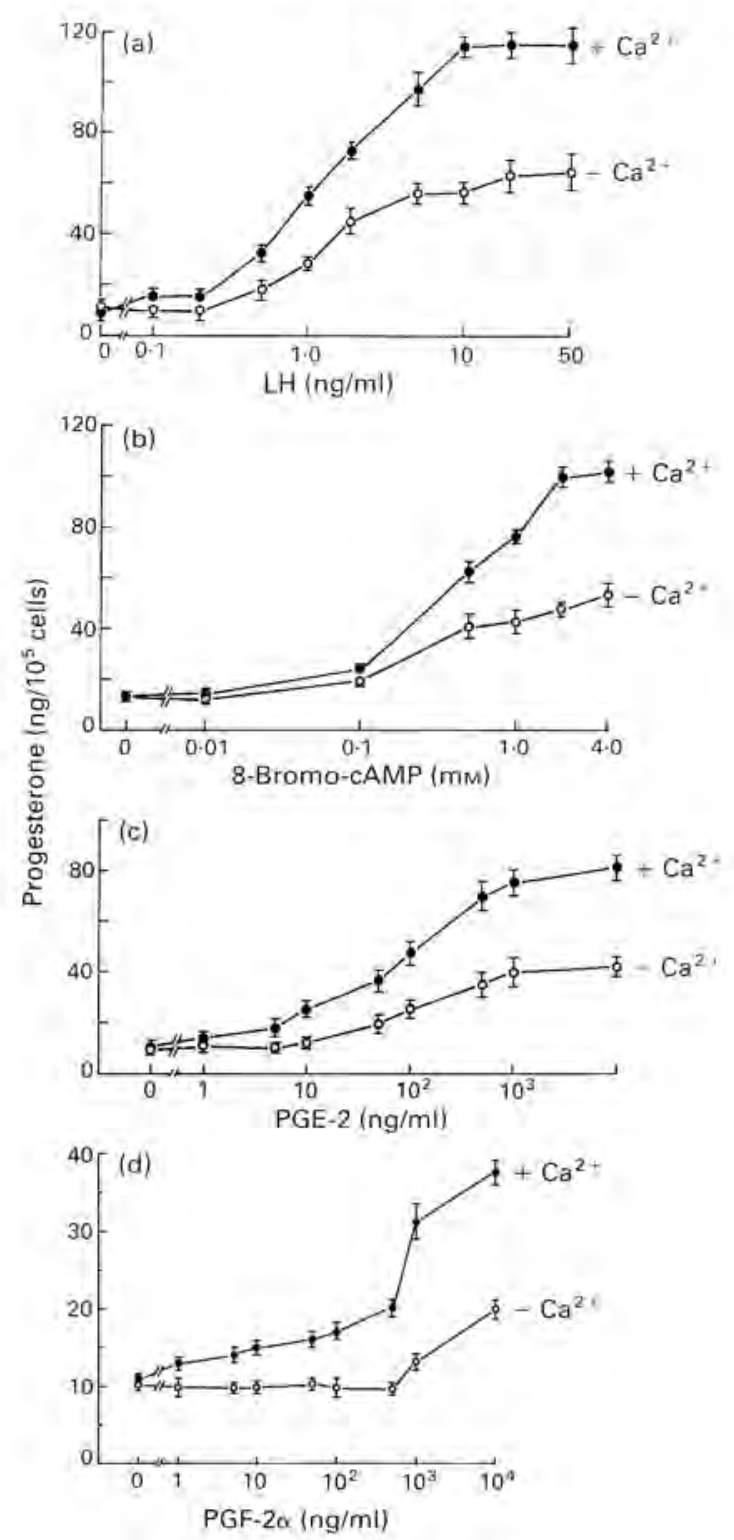

Fig. 2. The effect of calcium deprivation on progesterone production by small luteal cells in response to increasing concentrations of (a) LH, (b) 8-bromo-cAMP. (c) prostaglandin $\mathrm{E}_{2}$, and (d) prostaglandin $\mathrm{F}-2 \alpha$. The cells were incubated in 3 replicates per treatment per CL in the presence of $2.0 \mathrm{~mm}$-calcium $\left(+\mathrm{Ca}^{2+}\right)$ or $5 \mu \mathrm{M}$-calcium $\left(-\mathrm{Ca}^{2+}\right)$ in Medium 199 for $2 \mathrm{~h}(n=3)$.

Values are mean \pm s.e.m.

inhibitor of calmodulin/protein kinase $\mathrm{C}$, N-(6-aminohexyl)-5-chloro-1-naphthalene sulphonamide (W-7) inhibited both basal and LH-stimulated progesterone production in large and small cells, suggesting that calmodulin may be an intracellular regulator of basal progesterone production, at least in the large cells.

Transmembrane signalling of second messengers by LH and PGF-2 $\alpha$ in mixed populations of bovine luteal cells has been demonstrated to involve increases in $\left[\mathrm{Ca}^{2+}\right]_{\mathrm{i}}$ (Davis et al., 1987, 1988), However, the magnitude and profile of intracellular calcium changes induced by LH differ greatly 
in the two cell types, as shown by Alila et al.,(1989). In these studies $\left[\mathrm{Ca}^{2+}\right]_{i}$ was monitored in each cell type, after pre-loading them with fura $2 / \mathrm{AM}$, by a computer-driven spectrofluorometer (Spex $\mathrm{CM}-1-\mathrm{T} 111)$. Fluorescence was determined in suspensions of $5 \times 10^{5}$ small and $2 \times 10^{5}$ large cells at 3-sec intervals. Addition of LH to the small cells was followed immediately by a rapid transient rise in $\left[\mathrm{Ca}^{2+}\right]_{i}$ followed by a secondary elevation that was maintained for the duration of the experiment. Addition of a calcium chelator, EGTA, to the medium abolished the secondary rise (Fig. 3). These two-phase responses are similar to hormonal responses seen in other cell types after hormone stimulation and the first phase is generally interpreted as being due to mobilization of intracellular $\left[\mathrm{Ca}^{2+}\right]_{\mathrm{i}}$ by $\mathrm{IP}_{3}$ and triggering of a $\mathrm{Ca}^{2+}$ influx by inositol 1,3,4,5-tetrakisphosphate. The secondary phase is a result of influx of $\mathrm{Ca}^{2+}$ from extracellular sources, as indicated by the fact that it disappears after addition of EGTA.

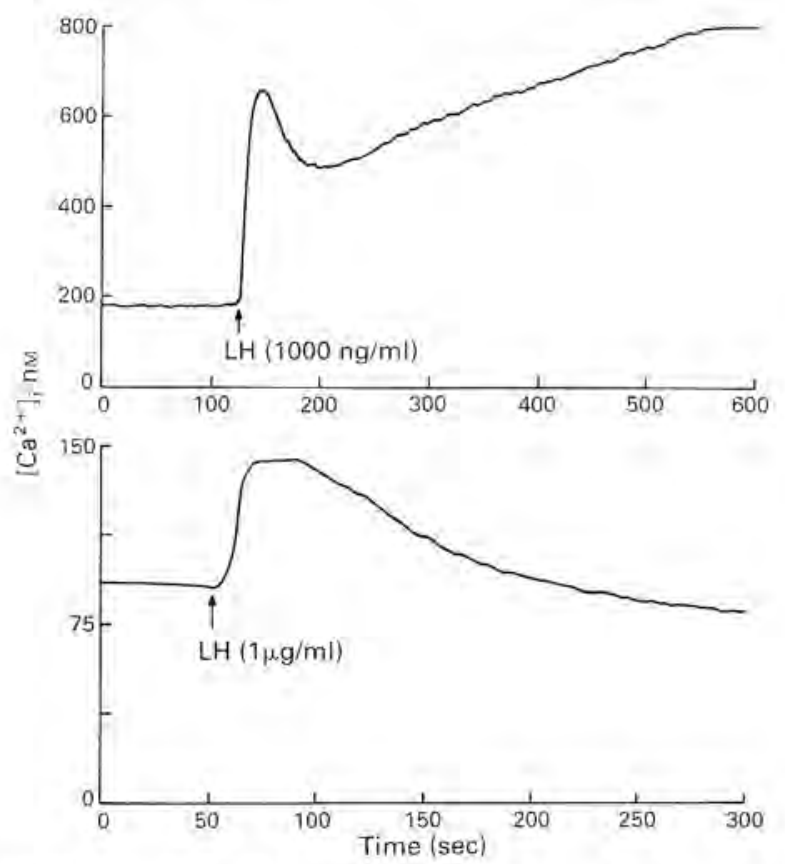

Fig. 3. $\mathrm{LH}$ effects on $\left[\mathrm{Ca}^{2+}\right]_{\mathrm{i}}$ in small luteal cells. $\left[\mathrm{Ca}^{2+}\right]_{\mathrm{i}}$ was monitored by dual excitation spectrofluorometry in fura-2-loaded cells. (a) A tracing of a representative experiment in which LH was added as indicated by the arrow. (b) A tracing of a representative experiment in which LH was added after preincubation of the cells in Medium 199 containing 5 mM-EGTA for $5 \min (n=4)$.

In contrast, only a single phase of $\left[\mathrm{Ca}^{2+}\right]_{\mathrm{i}}$ increase was observed in LH-treated large cells and this was abolished by addition of EGTA, indicating that the $\mathrm{LH}$-induced $\left[\mathrm{Ca}^{2+}\right]_{i}$ rise in these cells is entirely dependent on influx from an extracellular source. The two $\left[\mathrm{Ca}^{2+}\right]_{\mathrm{i}}$ phases induced by $\mathrm{LH}$ in the small cells are therefore due to $\mathrm{Ca}^{2+}$ mobilization from both intra- and extra-cellular sources, while in the large cells it is primarily due to $\mathrm{IP}_{3}$-independent extracellular ion influx.

These responses of $\left[\mathrm{Ca}^{2+}\right]_{i}$ to $\mathrm{LH}$ are consistent with the results of the studies cited above and they suggest a functional correlation between LH-stimulated progesterone production and intracellular $\mathrm{Ca}^{2+}$ in both cell types. The responses observed in each cell type are qualitatively identical to their responses in progesterone production. Small cells are more responsive to LH than large cells in $\left[\mathrm{Ca}^{2+}\right]_{i}$ and progesterone production, even though their resting $\left[\mathrm{Ca}^{2+}\right]_{i}$ level and basal progesterone production rate is lower. Surprisingly, LH has no effect on $\left[\mathrm{Ca}^{2+}\right]_{i}$ in either large or 
small cultured luteal cells in the ewe (Wiltbank et al., 1989b). However, Kong et al, (1989) reported that LH also fails to stimulate progesterone secretion by cultured ovine luteal cells.

PGF- $2 \alpha$, which unlike LH has no effect on cAMP generation, increases $\left[\mathrm{Ca}^{2+}\right]_{i}$ in both small (Alila et al., 1990) and large (Alila et al., 1989) bovine luteal cells. In the small cells the increase occurs in two phases, one representing mobilization of $\mathrm{Ca}^{2+}$ from intracellular sites and a later phase representing influx from extracellular calcium. In the large cells, PGF-2 $\alpha$, which inhibits LH-induced progesterone synthesis, also causes a rapid and transient rise in $\left[\mathrm{Ca}^{2+}\right]_{i}$ followed by a secondary sustained rise. When large cells are treated with both $\mathrm{LH}$ and PGF- $2 \alpha$ a remarkable rise in $\left[\mathrm{Ca}^{2+}\right]_{\mathrm{i}}$ occurs (Fig. 4). This increase is several times greater than the total of that induced by each hormone separately and results in $\left[\mathrm{Ca}^{2+}\right]_{\mathrm{i}}$ levels that could be cytotoxic. This interaction between LH and PGF-2 $\alpha$ suggests that calcium may be involved in the luteolytic process. In addition to inhibiting the ability of $\mathrm{LH}$ to stimulate progesterone production in the large cells, PGF-2 $\alpha$ stimulates levels of $\left[\mathrm{Ca}^{2+}\right]_{i}$ sufficiently high to cause transport and exocytosis of oxytocincontaining secretory granules (Chegini \& Rao, 1987).

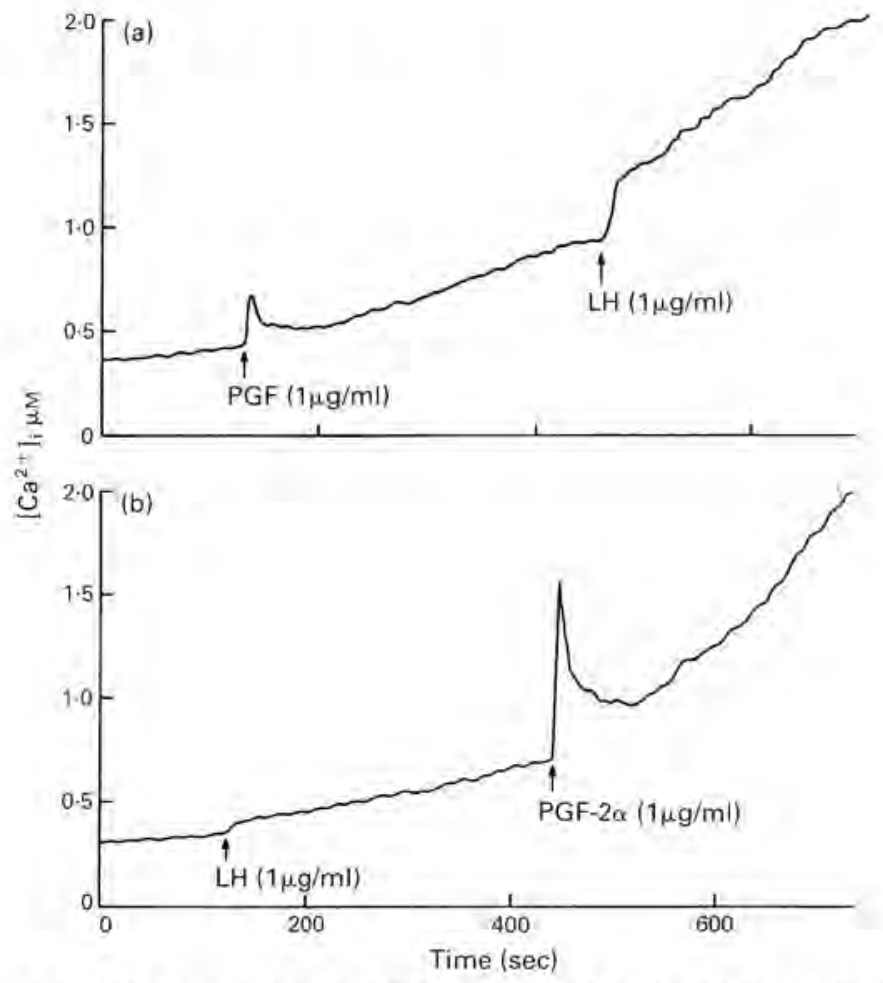

Fig. 4. Increases in $\left[\mathrm{Ca}^{2+}\right]_{\mathrm{i}}$ in response to PGF-2 $\alpha$ followed by the addition of $\mathrm{LH}(\mathrm{a})$, and $\mathrm{LH}$ followed by PGF-2a (b) in large luteal cells. The cells were exposed to each hormone for a similar period of time before adding the other hormone. The arrows indicate the time of addition of the hormones $(n=4)$.

\section{Role of arachidonic acid in bovine luteal cells}

Early studies aimed at identification of the bovine endometrial luteolytic factor(s) resulted in the isolation and identification of arachidonic acid as a luteolytic substance capable of regressing the 
corpora lutea and decreasing plasma progesterone concentrations in pseudopregnant hysterectomized hamsters (Hansel et al., 1975). Soon thereafter it was demonstrated in in-vivo studies that arachidonic acid injected directly into the bovine corpus luteum is rapidly converted to PGF-2 $\alpha$, resulting in immediate increases in ovarian venous PGF- $2 \alpha$ and jugular oestrogen concentrations, followed by declines in jugular plasma progesterone (Shemesh \& Hansel, 1975a).

Bovine luteal and endometrial tissues each contain relatively large amounts of arachidonic acid, but the concentration in endometrial tissue is only about one-sixth as high as in luteal tissue (Lukaszewska \& Hansel, 1980). The source(s) of these large amounts of arachidonic acid in bovine luteal tissues is not clearly defined. It has long been known that bovine luteal tissues have the ability to incorporate $\left[1-{ }^{14} \mathrm{C}\right]$ acetate into polyunsaturated acids, including arachidonic, docosatetraenoic and docosapentaenoic acids (Scott et al., 1968). However, bovine luteal tissue also has a remarkable capacity to bind tritiated arachidonic acid. The binding in luteal tissue exceeds that in skeletal muscle and ovarian stromal tissue by 7 times (Shemesh \& Hansel, 1975b). Part of the arachidonic acid found in the corpus luteum could be of endometrial origin.

In view of these facts and the fact that the hormone-mediated breakdown of polyphosphoinositides through activation of either calcium-dependent phospholipase A-2 or phospholipase C and diacylglycerol lipase leads to liberation of arachidonic acid (Wasserman, 1988), we decided to study the effects of arachidonic acid on intracellular calcium $\left[\mathrm{Ca}^{2+}\right]$ in large and small bovine luteal cells, using the methods described above (Alila et al., 1990).

Arachidonic acid elicited a dose-dependent increase in $\left[\mathrm{Ca}^{2+}\right]_{i}$ in the large and small luteal cells, having an effect in small cells at concentrations as low as $5 \mu \mathrm{M}$ and being maximally effective at $50 \mu \mathrm{M}$ (Fig. 5). Comparable concentrations of fatty acids with shorter or similar chain lengths failed to increase, or had only minimal effects on, $\left[\mathrm{Ca}^{2+}\right]_{i}$, indicating that arachidonic acid acts specifically on luteal cells to increase $\left[\mathrm{Ca}^{2+}\right]_{\mathrm{i}}$. Eicosapentaenoic acid $(20: 5)$ caused a small, but statistically significant $(P<0 \cdot 05)$, increase in $\left[\mathrm{Ca}^{2+}\right]_{i}$.

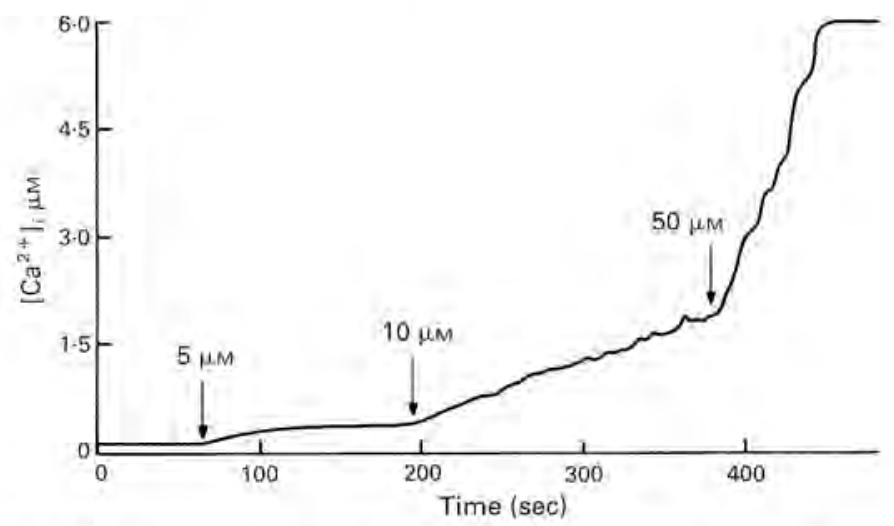

Fig. 5. Increases in $\left[\mathrm{Ca}^{2+}\right]_{i}$ in small luteal cells after sequential addition of increasing concentrations of arachidonic acid (arrows) $(n=3)$.

As was the case for $\mathrm{LH}$, there were two components of the arachidonic acid effects in small cells; one consisting of mobilization of $\left[\mathrm{Ca}^{2+}\right]_{i}$ from intracellular sources and one from extracellular sources. Again, mobilization of calcium in large cells was mainly from extracellular sources,

Additions of inhibitors of the cyclooxygenase and lipoxygenase pathways of arachidonic acid metabolism, at concentrations previously shown to inhibit prostanoid synthesis in bovine luteal 
cells, were ineffective in suppressing the calcium mobilizing actions of arachidonic acid, suggesting that mobilization of $\left[\mathrm{Ca}^{2+}\right]_{\mathrm{i}}$ was at least partly due to a direct action of arachidonic acid. However, both inhibitors (indomethacin and nordihydroguaiaretic acid) were themselves capable of elevating $\left[\mathrm{Ca}^{2+}\right]_{i}$ to a degree, Collectively, the results suggest that products of both the lipoxygenase and cyclooxygenase pathways, as well as arachidonic acid itself, may be involved in mobilization of $\left[\mathrm{Ca}^{2+}\right]_{i}$ in bovine luteal cells.

These results and those cited above (Fig. 4) demonstrating a synergistic action of LH and arachidonic acid and/or its metabolites in increasing $\left[\mathrm{Ca}^{2+}\right]_{i}$ suggest a role for arachidonic acid and $\left[\mathrm{Ca}^{2+}\right]$ in inducing luteolysis in bovine corpora lutea. This possibility is perhaps best illustrated by results of an experiment performed some years ago (Hansel \& Fortune, 1978) in which arachidonic acid was infused directly into a branch of the ovarian artery of heifers in which all connections between the ovarian pedicle and the uterus were severed. Separation of the uterus and the ovary in this way resulted in prolonged maintenance of the corpus luteum, as occurs after removal of the uterine horn ipsilateral to the corpus luteum, in all of the control animals. However, luteal regression and a marked decline in plasma progesterone concentrations occurred in 5 of 6 treated heifers. These results indicate that, given enough arachidonic acid, the bovine corpus luteum is capable of inducing its own regression.

Although further studies are needed, an increasing body of evidence suggests that arachidonic acid may play both direct and indirect roles in regulating intracellular calcium and the secretion of both oxytocin and progesterone by the bovine corpus luteum.

Table 2. A comparison of the effects of calcium on progesterone production in bovine luteal cells

Small cells Large cells

(1) Basal progesterone production does not require $\mathrm{Ca}^{2+}$. LH-stimulated production requires $\mathrm{Ca}^{2+}$

(2) Basal progesterone not affected by TMB-8; stimulated progesterone inhibited by TMB- 8

(3) $\mathrm{Ca}^{2+}$ effects are distal to cAMP

(4) W-7 inhibits both basal and stimulated progesterone production

(5) Verapamil has no effect on progesterone production

(6) Resting levels of $\left[\mathrm{Ca}^{2+}\right]_{\mathrm{i}}$ and basal production are relatively low

(7) Low levels of $\mathrm{LH}$ increase $\left[\mathrm{Ca}^{2+}\right]_{1}$ and progesterone synthesis 6 -fold

(8) LH induced $\left[\mathrm{Ca}^{2+}\right]_{\mathrm{i}}$ rise occurs in two phases (intra-and extra-cellular mobilization)

(9) AA specifically increases $\left[\mathrm{Ca}^{2+}\right]$; in two phases. Products of the cyclooxygenase and lipoxygenase pathways also increase $\left[\mathrm{Ca}^{2+}\right]_{i}$

(1) Both basal and LH-stimulated progesterone production require $\mathrm{Ca}^{2+}$

(2) Both basal and stimulated progesterone production inhibited by TMB-8

(3) $\mathrm{Ca}^{2+}$ effects are proximal to cAMP

(4) W-7 inhibits both basal and stimulated P production

(5) Verapamil has no effect on progesterone production

(6) Resting levels of $\left[\mathrm{Ca}^{2+}\right]_{1}$ and basal progesterone production are high

(7) High levels of LH increase $\left[\mathrm{Ca}^{2}\right]_{\mathrm{i}}$ and progesterone production 1.5-2-fold

(8) LH induced $\left[\mathrm{Ca}^{2 *}\right]_{i}$ rise occurs in one phase (extracellular mobilization only)

(9) AA increases $\left[\mathrm{Ca}^{2+}\right]_{i}$ in one phase. PGF- $2 \alpha$ and $\mathrm{LH}$ synergize to produce extremely high $\left[\mathrm{Ca}^{2+}\right]_{\mathrm{i}}$. AA may control oxylocin release by exocytosis of secretory granules

TMB-8 = 8-N,N-diethylaminocytyl-3,4,5-trimethoxybenzoate an inhibitor of intracellular calcium release or action; cAMP = cyclic AMP; W-7 = N-(6-aminohexyl)-5-chloro-1-naphthalene sulphonamide, a calmodulin protein kinase $\mathrm{C}$ antagonist: $\left[\mathrm{Ca}^{2 \downarrow}\right]_{\mathrm{i}}=$ intracellular calcium: $\mathrm{AA}=$ arachidonic acid; $\mathrm{PGF}-2 \alpha=$ prostaglandin $\mathrm{F}-2 \alpha$.

\section{Summary and Conclusions}

Studies of the calcium requirement and the relationship of intracellular calcium to progesterone synthesis in highly purified preparations of bovine luteal cells reveal a remarkably close 
relationship between intracellular calcium levels and steroidogenesis. The differential responses of the two cell types, summarized in Table 2, are beginning to reveal how the two cell types may co-operate to produce both luteotrophic and luteolytic responses at different stages of the oestrous cycle and early pregnancy. The luteotrophic mechanisms in the small cells are fairly clear; in addition to the luteotrophic effects of LH and CAMP, activation of protein kinase C leads to increased progesterone synthesis. Accordingly, PGF-2 $\alpha$ and several other prostanoids are luteotrophic in these cells. PGF-2a stimulates phospholipase $\mathrm{C}$ activity in the small cells but does not reduce LH-stimulated cAMP or progesterone accumulation (Davis et al., 1989). This acute stimulus of protein kinase $\mathrm{C}$ activation to progesterone production in bovine small luteal cells is rapidly desensitized, although its stimulus to prostanoid production continues for at least $24 \mathrm{~h}$.

Large cells respond to $\mathrm{LH}$, but only at relatively high levels. In addition, we have no good evidence for a role for protein kinase $\mathrm{C}$ in the control of progestrone synthesis in the large bovine luteal cells from mid-cycle corpora lutea. Phorbol esters have no effect on steroidogenesis and it is not yet established that protein kinase $\mathrm{C}$ provides the same high affinity receptor for phorbol esters that is found in the small cells. Experiments with inhibitors of protein kinase C, such as staurosporine, in large cells have been inconclusive.

Evidence for several species suggests that both cell types co-operate, in ways not yet fully understood, to bring about maximal progesterone production at mid-cycle. Some evidence suggests that they may also co-operate to bring about luteolysis. The concept that PGF-2 $\alpha$ initiates luteolysis by inhibiting LH stimulated progesterone production in the large cells must be revised in light of the relative insensitivity of these cells to $\mathrm{LH}$ and the fact that they probably constitutively express the cholesterol side-chain cleavage enzymes $\left(\mathrm{P}-450_{\text {scc }}\right)$ that represent the rate-limiting step in progesterone production. Oonk et al. (1989) have reported that, once $\mathrm{P}-450_{\mathrm{sec}} \mathrm{mRNA}$ is induced in rat granulosa cells by the LH surge, it is constitutively maintained by the luteinized cells in the absence of gonadotrophins and is no longer regulated by cAMP.

The remarkable ability of arachidonic acid and some of its metabolites to mobilize intracellular calcium suggests the following sequence of events as a working hypothesis for the initiation of luteolysis.

(1) Activation of protein kinase $\mathrm{C}$ in small cells results initially in increased progesterone production and increased production of arachidonic acid and its metabolites (PGF-2 $\alpha$, PGE-2 and PGI-2), which are luteotrophic in small cells. However, chronic activation of protein kinase C in small cells desensitizes LH-induced progesterone production, while prostanoid production continues unabated.

(2) The high levels of arachidonic acid and/or its metabolites induced by protein kinase $\mathrm{C}$ result in unphysiologically high levels of intracellular calcium in the large cells. Arachidonic acid and other highly unsaturated long-chain fatty acids (eicosapentaenoic, docosatetraenoic and docasapentaenoic) may have direct luteolytic effects as a result of their abilities to elevate intracellular calcium.

(3) The high levels of intracellular calcium induce luteolysis in the granulosa-derived large cells; possibly by causing exocytosis of oxytocin-containing secretory granules and perhaps also by direct effects on the cell, including calcium-activated DNA fragmentation leading to programmed cell death, or apoptosis (McConkey et al, 1989).

(4) Finally, inhibitory substances released from granulosa-derived large cells act directly to reduce steroidogenesis in small cells. Oxytocin released from large cells may also be transported to the uterus where it causes the release of additional arachidonic acid and/or PGF- $2 \alpha$.

The experiments described were supported by USDA Grant No. 85-CRCR-1-1830 and the Northeast Regional Research Project, NE-161, We thank Dr John S. Davis, The Women's Research Institute, Wichita, KS, for co-operation with several of the experiments cited; R. Saatman and D. Bianchi for technical assistance; and Virginia Slator for secretarial assistance. 


\section{References}

Alila, H.W. \& Hansel, W. (1984) Origin of different cell types in the bovine corpus lateum as characterized by specific monoclonal antibodies. Biol. Reprod. 31, 1015-1025.

Alila, H.W., Dowd, J.P., Corradino, R.A., Harris, W.V. \& Hansel, W. (1988a) Control of progesterone production in small and large bovine luteal cells separated by flow cytometry. J, Reprod. Fert. 83, 645-655.

Alila, H.W., Corradino, R.A. \& Hansel, W. (1988b) A comparison of the effects of cyclooxygenase prostanoids or progesterone production by small and large bovine luteal cells, Prostaglandins 36, 259-270.

Alila, H.W., Dowd, J. \& Corradino, R.A. (1988c) The role of calcium in progesterone synthesis by small and large bovine luteal cells. Biol. Reprod. (Suppl. I), 55, abstr.

Alila, H.W., Corradino, R.A. \& Hansel, W. (1989) Differential effects of luteinizing hormone on intracellular free $\mathrm{Ca}^{2+}$ in small and large bovine luteal cells. Endocrinology 124, 2314-2320.

Alila, H.W., Corradino, R.A. \& Hansel, W. (1990) Arachidonic acid and its metabolites increase cytosolic free calcium in bovine luteal cells. Prostaglandins 39, $481-496$.

Armstrong, D.T. \& Black, D.L. (1966) Influence of luteinizing hormone on corpus luteum metabolism and progesterone biosynthesis throughout the bovine estrous cycle. Endocrinology 78, 937-945.

Brunswig, B., Mukhopadhyay ${ }_{\dagger}$ A.K., Budnik, L.T., Bohnet, H.G. \& Leidenberger, F.A. (1986) Phorbol ester stimulates progesterone production by isolated bovine luteal cells. Endocrinology 118, 743-749.

Casida, L.E. (1960) Research techniques in physiology of reproduction. In Techniques and Procedures in Animal Production. Am. Soc. Animal Prod., p. 1061.

Chegini, N. \& Rao, C.V. (1987) Dynamics of nuclear associated granules in bovine luteal cells after treatment in vitro with prostaglandin F-2a, Endocrinology. 121, 1870-1878.

Corner, G.W. (1919) On the origins of the corpus luteum of the sow from both granulosa and theca interna. Am. J. Anat. 26, 117-183.

Corner, G.W. (1945) Development, organization and breakdown of the corpus luteum of the rhesus monkey. Contr. Carn. Inst. Embryol, 204, 117-146.

Davis, J.S., Weakland, L.L., Farese, R.V. \& West, L.A. (1987) Luteinizing hormone increases inositol triphosphate and cytosolic free $\mathrm{Ca}^{2+}$ in isolated bovine luteal cells. J. biol. Chem. 262, 8515-8521.

Davis, J.S., Alila, H.W., West, L.A., Corradino, R.A. \& Hansel, W. (1988) Acute effects of prostaglandin F-2 $\alpha$. on inositol phospholipid hydrolyses in the large and small cells of the bovine corpus luteum. Molec. cell. Endocrinol. 58, 43-50.

Davis, J.S., Alila, H.W., West, L.A., Corradino, R.A., Weakland, L.L. \& Hansel, W. (1989) Second messenger systems and progesterone secretion in the small cells of the bovine corpus luteum: Effects of gonadotropins and prostaglandin E-2a. I. Steroid Biochem. 32, 643-649.

Donaldson, L.E. \& Hansel, W. (1965) Histological study of bovine corpora lutea. J. Dairy Sci. 48, 905-909.
Dowd, J.P., Alila, H.W. \& Hansel, W. (1990) Phorbolester receptors in bovine luteal cells: relationship to protein kinase C. Molec. cell. Endocrinol. 69, 199-206.

Farin, C.E., Sawyer, H.R. \& Niswender, G.D. (1989) Analysis of cell types in the corpus luteum of the sheep. J. Reprod. Fert., Suppl. 37, 181-187.

Fletcher, P.W. \& Niswender, G.D. (1982) The effect of PGF- $2 \alpha$ on progesterone secretion and adenylate cyclase activity in ovine luteal tissue, Prostaglandins 23, 803-818,

Hansel, W. \& Dowd, J.P. (1986) Hammond Memorial Lecture: New concepts of control of corpus luteum function. J. Reprod. Fert. 78, 755-768.

Hansel, W. \& Fortune, J.E. (1978) The application of ovulation control. In Control of Qvulation, pp. $237-$ 263. Eds D. B. Crighton, N. B. Haynes, G. R. Foxcroft \& G. E. Lamming. Butterworth Scientific, London.

Hansel, W. \& Seifert, K.H. (1967) Maintenance of luteal function in the dairy cow. J. Dairy Sci. 50, 1948-1958.

Hansel, W., Concannon, P.W. \& Lukaszewska, J. (1973) Corpora lutea of the large domestic animals. Biol. Reprod. 8, 222-245.

Hansel, W., Shemesh, M., Hixon, J. \& Lukaszewska, J. (1975) Extraction, isolation and identification of a luteolytic substance from bovine endometrium. Biol. Reprod. 13, 30-37.

Hansel, W., Alila, H.W., Dowd, J.P. \& Yang, X. (1987) Control of steroidogenesis in small and large bovine luteal cells. Aust. J, biol. Sci 40, 331-347.

Hansen, T.R., Randel, R.D., Segerson, E.C., Jr, Rutter, L.M. \& Harms, P.G. (1987) Corpus luteum function following spontaneous or prostaglandin-induced estrus in Brahman cows and heifers. J. Anim. Sci. 65, 524-533.

Harrison, L.M., Kenny, N. \& Niswender, G.D. (1987) Progesterone production, LH receptors and oxytocin secretion by ovine luteal cell types on Days 6, 10 and 15 of the oestrous cycle and Day 25 of pregnancy. J. Reprod Fer1. 79, 539-548.

Hixon, J.E. \& Hansel, W. (1979) Effects of prostaglandin $\mathrm{F}-2 \alpha$, estradiol and luteinizing hormone in dispersed cell preparations of bovine corpora lutea. In Ovarian Follicular and Corpus Luteum Function, pp, 613-620. Eds C. P. Channing \& J. M. Marsh. Plenum, New York.

Hoyer, P.B. \& Marion, S.L. (1989) Influence of agents that affect intracellular calcium regulation on progesterone secretion in small and large futeal cells of the sheep, J. Reprod. Ferl, 86, 445-455.

Kong, W., Marion, S.L. \& Hoyer, P.B. (1989) Luteotropic and luteolytic responsiveness of ovine luteal cells in long term culture. Biol. Reprod. 41, 707-714.

Koos, R.D. \& Hansel, W. (1981) The large and small cells of the bovine corpus luteum: ultrastructural and functional differences. In Dynamics of Ovarian Function, pp. 197-203. Eds N. B. Schwartz \& M. HunzickerDunn. Raven Press, New York.

Lemon, M. \& Mauléon, P. (1982) Interaction between two luteal cell types from the corpus luteum of the cow in progesterone synthesis in vitro. J. Reprod. Fert. 64, 315-323. 
Lukaszewska, J. \& Hansel, W. (1980) Corpus luteum maintenance during early pregnancy in the cow. $J$. Reprod. Fert. 59, 485-493.

McConkey, D.J., Hartzell, P., Nicotera, P. \& Orrenius, S. (1989) Calcium activated DNA fragmentation kills immature thymocytes. The FASEB Journal 3, 1843 1849.

McCracken, J.A., Baird, D.T. \& Goding, J.R. (1971) Factors affecting the secretion of steroids from the transplanted ovary in the sheep. Recent Progr. Hormone Res. 27, 557-647.

McNutt, G.W. (I924) The corpus luteum of the ox ovary in relation to the oestrous cycle. $J$. Am, vet, med. Assoc. 65, 556-597.

Oonk, R.B., Knasnow, J.S., Beattie, W.G. \& Richards, J.S. (1989) Cyclic AMP-dependent and -independent regulation of cholesterol side chain cleavage cytochrome P-450 (P-450 ${ }_{\text {sec }}$ in rat ovarian granulosa cells and corpora lutea. J. biol. Chem. 264, 21934-21942.

O'Shea, J.D., Rogers, R.J. \& D'Occhio, M.J. (1989) Cellular composition of the cyclic corpus luteum of the cow. J. Reprod. Fert. 85, 483-487.

Savard, K. (1973) The biochemistry of the corpus luteum. Biol. Reprod. 8, 183-202.

Schwall, R.H., Sawyer, H.R. \& Niswender, G.D. (1986) Differential regulation of $\mathrm{LH}$ by prostaglandins of steroidogenesis in small and large luteal cells of the ewe. J. Reprod. Fert. 76, 821-829.
Scott, T.W., Hansel, W. \& Donaldson, L.E. (1968) Metabolism of phospholipids and the characterization of fatty acids in bovine corpus luteum. Biochem. J. 108, 317-322.

Shemesh, M. \& Hansel, W. (1975a) Arachidonic acid and bovine corpus luteum function. Proc. Soc, exp. Biol. Med. 148, 243-246.

Shemesh, M. \& Hansel, W. (1975b) Stimulation of prostaglandin synthesis in bovine ovarian tissues by arachidonic acid and luteinizing hormone. Biol. Reprod 13, 448-452.

Smith, R.D., Pomerantz, A.J., Beal, W.E., McCann, J.P., Pilbeam, T.E. \& Hansel, W. (1984) Insemination of Holstein heifers at a preset time after estrous cycle synchronization using progesterone and prostaglandin. J. Anim. Sci. 58, 792-811.

Wasserman, R.J, (1988) Cellular Calcium: Action of Hormones. In Calcium in Human Biology, pp. 385 419. Ed. B. C. C. Norden. Springer-Verlag, London.

Wiltbank, M.C., Knickerbocker, J.J. \& Niswender, G.D. (1989a) Regulation of the corpora lutea by protein kinase C 1. Phosphorylation activity and steroidogenic action in large and small ovine luteal cells. Biol. Reprod. 40, 1194-1200.

Wiltbank, M.C., Guthrie, P.B., Mattson, M.P., Kater,S.B. \& Niswender, G.D. (1989b) Hormonal regulation of free intracellular calcium concentrations in small and large ovine luteal cells. Biol. Reprod. 41, 771-778. 
